\title{
Tradition and Japanese Social Organization: Institutional Development in a Tokyo Neighborhood
}

\section{Citation}

Bestor, Theodore C. 1985. Tradition and Japanese social organization: Institutional development in a Tokyo neighborhood. Ethnology 24(2): 121-135.

\section{Published Version}

doi: $10.2307 / 3773554$

\section{Permanent link}

http://nrs.harvard.edu/urn-3:HUL.InstRepos:3964903

\section{Terms of Use}

This article was downloaded from Harvard University's DASH repository, and is made available under the terms and conditions applicable to Other Posted Material, as set forth at http:// nrs.harvard.edu/urn-3:HUL.InstRepos:dash.current.terms-of-use\#LAA

\section{Share Your Story}

The Harvard community has made this article openly available.

Please share how this access benefits you. Submit a story.

Accessibility 


\title{
Tradition and Japanese Social Organization: Institutional Development in a Tokyo Neighborhood $^{1}$
}

\author{
Theodore C. Bestor \\ Social Science Research Council, New York
}

Older sections of Japanese cities often are divided into well-defined neighborhoods. These are not simply bureaucratic devices (such as postal districts or police precincts) with little correspondence to the social categories and groupings important in the daily lives of most local residents. Nor are such neighborhoods merely emblems of larger social, economic, or ethnic divisions within the citysuch as a New Yorker might have in mind when referring to the West Village, Wall Street, or Williamsburg. Rather, these neighborhoods are geographically compact and spatially discrete; socially they are well-organized and cohesive, containing from several hundred to a few thousand residents. In such neighborhoods, overlapping and intertwining local organizations and institutions provide a wide array of services and sponsor myriad activities for local residents, who are also linked to one another by elaborate, enduring webs of informal social, economic, and political ties that extend throughout the neighborhood.

Yet neighborhood groups and ties are often transparent or invisible to casual observers, known only to residents for whom the local services, contacts, and activities neighborhoods foster are important. They are invisible, too, because scholars rarely examine the substance and significance of neighborhood social life, and instead dismiss urban community institutions as ephemeral, regarding them either as merely the government's administrative creations or as residual products of outmoded patterns of social organization.

One Tokyo neighborhood in which these transparent institutions form a vigorous and important arena for local social life is Miyamoto-chō ${ }^{2}$, where I carried out fieldwork from June 1979 to May I98I. Miyamoto-Chō is about twenty minutes by commuter train from Tokyo station in an older section of the city. A rough rectangle measuring about 200 by 400 meters, Miyamoto-chō contains about 2,100 residents in 930 households ${ }^{3}$; the neighborhood's population density approaches 30,000 residents per square kilometer. Its jumbled homes and apartment buildings are interspersed with about 120 small shops and 40 tiny factories, almost all of which are owned and operated as household enterprises. The neighborhood is a middle and lower-middle class community, dominated socially, politically, and commercially by the self-employed merchants and manufacturers for whom Miyamoto-chō is both home and workplace.

This article shows that neighborhood institutions and the informal ties that crosscut and link them are not ephemeral, but crucial in the lives of many local residents. I argue that neither view of neighborhood life-as institutional invention or as static product of cultural tradition-sufficiently explains contem- 


\section{22 ETHNOLOGY}

porary patterns of social organization in this or many other domains of Japanese society.

\section{INSTITUTIONAL INVENTION VERSUS CULTURAL TRADITION}

Scholars advance two differing views of neighborhood social life in urban Japan. In one, they regard the social framework of urban neighborhoods as nothing more than administrative and political expedients created and dominated by local governments. In the other, analysts see the existence of such frameworks as evidence of the persistence of traditional, premodern, and feudal social customs and habits of mind. Yet, these views are not necessarily mutually exclusive; both rely on assumptions that culture is static and unmalleable, and that once in place neither patterns of social organization nor cultural values and beliefs can influence the other. Scholars who see these structural arrangements as administrative in origin, assume that imposed institutions do not become incorporated into or play a part in shaping culturally constructed behavior and beliefs. If cultural tradition is used to explain social patterns, culture is assumed to be immutable, ancient, and unaffected by social change.

When urban neighborhoods are under consideration, usually this debate centers on the significance of chonaikai ${ }^{4}$, or neighborhood associations, which are key institutions in the formal structure of many neighborhoods. Because of the important roles chönaikai and related organizations play in local government and politics, and particularly because of the notorious reputation these institutions acquired as instruments of government control during the Second World War (Masland I946; Supreme Commander for the Allied Powers I948, I949: I, 284-88; Havens I978:36-89), chönaikai have received attention from scholars interested in contemporary Japanese politics and recent political history (Allinson I979; Falconeri I976; McKean 1976, I981; White I976, I982). But most researchers focus on political problems or processes of a more general nature and only rarely make chonaikai themselves the primary objects of inquiry. They therefore tend to view neighborhood-level social relationships and activities in almost exclusively political and administrative terms.

If one emphasizes neighborhoods' political and administrative functions it is easy to see chonaikai and other neighborhood institutions as little more than extensions of the municipal government-created largely at the government's instigation, subservient to it, and manipulated by it to serve the government's ends. But this perspective assumes that chonaikai and local administrative agencies inevitably and invariably share common interests, and that smooth relationships always exist between them. It downplays the reality of neighborhoods-as social facts and as significant social arenas-for those who live within them. And it concentrates on political and administrative features of neighborhood structure to the exclusion of other, social aspects.

Yet these social aspects are important in helping Japanese city dwellers develop or maintain the sense of community and social solidarity that enables urban neighborhoods and their institutions to play effective administrative and political roles. As Allinson (I979:20I) remarks, "the mood created by these associations [is] in the end more important than any overt political actions they [may] have taken." Rather than stressing only these explicitly political or administrative aspects of community life, one must, therefore, examine the creation of this mood and the ongoing process that Suttles (1972) calls "the social construction of a community" to understand how such neighborhoods come into being and how they come to play both political and other roles.

By focusing on the conservative character of neighborhoods as political units and by equating this with cultural conservatism of neighborhood activists, scholars are often led to identify these patterns of neighborhood institutions and social relationships with the traditions of the rural past. They frequently take the 
contemporary existence of these community organizations as evidence of the enduring gemeinschaftlich character of Japanese urban society (Isomura and Okuda I966:I4I). Dore (1958:286) refers to the stable framework of neighborhood life as "already anachronistic ... institutions which properly belong to the self-contained village," while Falconeri (1976:34) sees cbōnaikai as "a product of Japanese village orientations carried over into the urban setting."

Some commentators consider these patterns of neighborhood life to be descended from the institutions of Japan's preindustrial urban traditions (Dore I968; Brown 1976), developed and best preserved in the old shitamachi ${ }^{5}$ merchant quarters of Japanese cities (Fukutake I98I; Ishida I97I), and maintained in the present day by the politically conservative and culturally traditional old middle class (Okuda I964). Others argue that the social organization of the preindustrial city differed only slightly in structure from that of the rural village. To Bellah (I957:43), "the [Tokugawa] city only to a limited extent represented a new form of social organization ... For many purposes it was merely a congeries of 'villages' in close geographic contiguity" (cf., R. J. Smith I960:253-54, I973: 164-65).

Whether scholars interpret the social patterns and institutions of contemporary urban neighborhoods as reiterations of buraku [rural hamlets], or as derivations of preindustrial merchant quarters, they share an assumption-common to many more general analyses of Japanese society - that traditional, rural Japan contains the fundamental essence of Japanese social structure (Nakane r 970:59-6I). Fukutake (1962:100), for example, identifies "the social character of the buraku [as] the prototype of Japanese society."

In these viewpoints analysts take as historical givens both the social patterns and the seemingly traditionalistic activities in which social relations are so often expressed. They rely on an "undynamic concept of culture ... inclined to discover sameness in seeming similarities over time" (Yanagisako, in press: 4-5). In doing so, they fail to examine the dynamic creation and re-creation of such social patterns and cultural beliefs that occur during historical processes of social and cultural change. They confuse tradition as historical continuity with traditionalism-the manipulation, invention, and recombination of cultural patterns, symbols, and motifs to legitimate contemporary social realities. By the same token, scholars who emphasize the administrative creation of social patterns and institutions in the recent past similarly ignore the capacity for institutional inventions to sink deep roots and quickly become wreathed in expressive cultural idioms that are as significant to participants as are any instrumental functions.

These issues are not limited to analyses of neighborhood associations. Traditionalistic elaborations of institutional inventions play as important a role in the development and maintenance of community institutions as they do in the creation of patterns of managerial paternalism, lifetime employment, group loyalty, consensual decision-making, and any of a dozen other aspects of contemporary Japanese life that are routinely assumed to reflect "traditional" Japanese values and practices.

By examining the historical development and the present-day social organization of Miyamoto-chō, I will illustrate: (a) that neighborhoods have social-rather than exclusively political-dimensions that are not confined to a neighborhood's institutional structure; (b) that present-day neighborhoods exist apart from their direct ties with administrative agencies; and (c) that the apparent traditionalism of patterns of neighborhood life is a recent cultural construct not evidence of historical continuities. I argue that the confusion of tradition with traditionalism-a feature not just of neighborhood social organization but of social patterns throughout contemporary Japan-leads scholars to overemphasize processes of historical continuity and the persistence of tradition, which distorts analysis of this and many other aspects of contemporary urban Japanese social organization. 


\section{The Historical Development of MiYamoto-CHO}

The history of Miyamoto-chō's development not only illustrates the discontinuity of contemporary institutions with what are often assumed to be the precursors of urban neighborhoods' social patterns, it also provides evidence that the creation of traditionalistic social institutions occurred simultaneously with urbanization. Finally, it illuminates the origins of present-day strains in the relationship between the neighborhood and the municipal government.

Until the I920s Miyamoto-chō simply did not exist. At the start of the Meiji period in I868, the area that has since become Miyamoto-chō and six other neighborhoods was an agricultural hamlet called Kumodani located three kilometers beyond the outermost fringes of Edo (as Tokyo was then known). In the I 88 os the national government forced the administrative mergers of thousands of hamlets, villages, and towns throughout Japan (Steiner I 965:46). Kumodani was amalgamated with four adjacent hamlets to create a new administrative village named Hiratsuka-mura, which remained an agricultural village until just after World War I.

Japan's economic boom during World War I led to the development of industry and the beginnings of urban growth in Hiratsuka-mura and other villages surrounding Tokyo (Shinagawa-ku Kyōiku Iinkai [hereafter cited as SKKI] I979:I9I-98), but the major impetus for the area's urbanization was the catastrophic Kantō earthquake of September I, I923, which killed an estimated $\mathrm{I} 00,000$ persons in the city of Tokyo and left 60 per cent of Tokyo's population homeless (SKKI I979: I98-200, 205). Not only was the human toll staggering, but the earthquake's demographic, cultural, social, and political consequences changed the course of Tokyo's history (Seidensticker I983; Kurabayashi 1983). Miyamoto-chō is merely one among hundreds of neighborhoods created in the chains of events launched by the earthquake.

After the earthquake, the suburban towns and villages that ringed Tokyo were flooded with refugees, and Hiratsuka-mura's population grew I,450 per cent (from 8,522 to I 32, I08) in the decade after I 920 (Tōkyō-fu I $921: 80$; I 930:68). ${ }^{6}$ In 1925 Hiratsuka-mura became a town, renamed Ebara-machi in I 926 . Sudden growth strained municipal services and bankrupted many suburban towns and villages. This and the spread of population far beyond the city's boundaries were major factors behind the annexation of Ebara-machi and $8 \mathrm{I}$ other towns and villages into an expanded city of Tokyo in I932 (Tōkyō-to I972-80: V, 623).

As these changes took place at the municipal level, other developments led to the creation within Hiratsuka-mura/Ebara-machi of identifiable neighborhoods, which did not grow out of previously existing local units. By the I920s no traces remained of political, administrative, or social groups that may have existed during the Meiji period (I868-I9I2) or earlier beneath the level of the hamlet (Inoue I932:92; Shinagawa-ku I973-74: II, 510). Hiratsuka-mura lacked any sub-village administrative system, and in response to the massive population influx it created forty-seven districts within the village in I925 (Ebara-kuyakusho I 943:237-38). What had been the hamlet of Kumodani encompassed eight of them. One of these roughly corresponded to what is now Miyamoto-chō, which for the first time was recognized as an administratively, socially, or spatially separate entity. These districts survived until I932 when Ebara-machi merged with the city of Tokyo and became a ward (Ebara-ku); thereafter the legal standing of these administrative districts disappeared because as a subunit in Tokyo's municipal government Ebara-ku could not be further subdivided.

In some areas of Hiratsuka/Ebara chönaikai had been founded as early as I923, well before the village-then-town's administrative districts. Within a year or two of the merger with Tokyo most neighborhoods in Ebara had established chōnaikai. The present-day Miyamoto-chō was among the last neighborhoods to 
organize a chōnaikai, in 1933 (Ebara-kuyakusho I943:583-609). These chönaikai did not necessarily correspond to the administrative districts. There had been 47 administrative districts in Hiratsuka/Ebara, but by the early I930s residents had organized 78 separate neighborhood associations (Ebara-kuyakusho 1943:557). These associations were involved in a great deal more than simply administrative activities and served a variety of locally defined needs; they prompted local business, managed shrine affairs, sponsored local festivals, assisted the poor, feted military inductees, and "promoted neighborly feelings" (Inoue I 932:83-5; Ebarakuyakusho I 943:240-3). Taking their boundaries from the territorial divisions residents defined as significant, chonnaikai paralleled the development of local community sentiment and identity. Their establishment aided the creation of frameworks for neighborhood life within which other formal and informal ties among residents could develop, local activities could be organized, and other local groups could be formed. The neighborhoods encompassed by these chonaikai became the basic units within which could develop the full range of community life then characteristic of Japanese urban society.

The development of institutions and the growth of sentiments of community identity within new neighborhoods, were not, however, merely a transplantation of existing patterns of urban neighborhood life into a newly urbanizing setting. On the contrary, the urbanization of Hiratsuka/Ebara occurred simultaneously with the development of neighborhood institutions throughout Tokyo. Scholars often assume formally organized neighborhood associations have been enduring, quintessentially traditional features of urban life, particularly in the old shitamachi merchant quarters of Tokyo. However, these organizations were created in the I 920 s and early I930s throughout all areas of Tokyo, both old and new. A I 934 survey of Tokyo's chōnaikai found that almost three-quarters (72.4 per cent) had been established since I923 and only 2 per cent antedated 1897; even in the central wards (presumably the most traditional areas) only 4 per cent of the chönaikai could trace their histories as far back as I 897 (Nakamura 1979:19).

Neighborhood associations developed while urban Japan, particularly Tokyo, was experiencing unprecedented growth and upheaval; economic, social, and political disruption accompanied the era's industrial growth, compounded in Tokyo by the after-effects of the Kantō earthquake. During the I920s and I930s, the national government launched various ideological campaigns to counter what were seen as threats to the established order. The government had long attempted to control potential sources of social, political, or economic unrest through the conscious creation and manipulation of traditionalistic values and institutions. Although most local groups had been created independently at local initiative (H. D. Smith I978; Hastings I 980), chönaikai and other social improvement groups were harnessed by the authorities in their efforts to control urban society, mobilizing traditional values that evoked feelings of solidarity reminiscent of rural hamlet life. Neighborhood associations were not accorded any formal, legal recognition until i938 (Steiner I965:2 I9), and soon afterward they were incorporated into the authoritarian administrative system developed before World War II.

In September, I 940 the national government required all communities to form neighborhood associations (called chökai or chōnaikai in urban areas, and burakukai in rural areas) as well as lower level groupings called tonarigumi, which consisted of a dozen or so neighboring households whose membership was compulsory. Shortly thereafter chōnaikai, burakukai, and tonarigumi were incorporated into the national political front, the Imperial Rule Assistance Association, which forged all political, social, and economic organizations into a single, tightly-controlled government body.

In Ebara-ku in I94 I the ward government redrew the boundaries of chonaikai and reduced their number from 78 to 58 , both to strengthen control over the 


\section{I26 ETHNOLOGY}

chōnaikai and to make more uniform their size and operations (Ebara-kuyakusho I 943:556-60). This reshuffle amalgamated one neighborhood with a fragment of another to establish the present-day boundaries of Miyamoto-chō.

During the war choonaikai and tonarigumi were active instruments of government control and regimentation. They were responsible for administering the rationing system, organizing civil defense, mustering labor for the war effort, disseminating propaganda, and encouraging mutual surveillance (Havens 1978:36-89). They were feared and hated institutions that, "reached into the lives of every citizen through a medium more effective than the very effective police" (Braibanti 1948: I39). The Allied Occupation's program to democratize Japanese society proscribed chōnaikai, burakukai, and tonarigumi in 1947 (Supreme Commander for the Allied Powers I949: I, 284-88). Throughout Japan, neighborhood associations survived the Occupation in a sub rosa existence (in Miyamoto-chō, as a "Crime Prevention League") before re-emerging openly in the I950s as citizens' organizations legally independent of the government.

The historical legacy of the prewar development of neighborhood institutions, their wartime role, and their abolition continue to affect postwar attitudes toward chönaikai and their relationships with the municipal government. Memories of prewar and wartime regimentation play an important if implicit role in shaping contemporary attitudes toward local institutions, and in influencing present-day interactions between local organizations and the government. The postwar disestablishment of chönaikai and the legal (if not actual) severing of ties between them and the government, introduced tensions that continues to exist in the relationship between chōnaikai and municipalities. These attitudes, plus longstanding conflicts within the Japanese political system between principles of local autonomy and centralized control, contribute to the enduring opposition between local and non-local that is so important a theme even today in Miyamotochō. This tension between the chönaikai and the municipal government is central to understanding contemporary neighborhood life in Miyamoto-chō, as I shall show in the following section.

The history of Miyamoto-chō's creation clearly demonstrates that the neighborhood-both as a physical settlement and as a framework of institutions-is the product of recent developments rather than of inherited patterns from the preindustrial past, either rural or urban. In Ebara-ku as elsewhere in Tokyo, neighborhood institutions were established in response to the same forces of population growth, urban expansion, and economic change that created the neighborhoods themselves. That local institutions took on such traditionalistic colorations is less evidence of their historical origins or of static continuity than it is a reflection of ideological currents that sought to "revive the past as a malleable ideal, not as an actuality" (Havens 1978:43).

\section{THE CONTEMPORARY NEIGHBORHOOD}

Today, Miyamoto-chō is an ordinary place similar to hundreds of other neighborhoods that stretch in a wide arc to the north, east, and south of central Tokyo. No visible signs of social, economic, or cultural distinctiveness set Miyamoto-chō apart from its surroundings. What makes Miyamoto-chō a discrete social unit-separate, but not significantly different-from nearby neighborhoods are the cross-cutting and overlapping institutions and relationships that define Miyamoto-chō as an entity and breathe life into this definition through the activities and interactions they promote.

\section{Formal Neighborhood Organizations}

Among the neighborhood's formal organizations, the most important are several quasi-voluntary, "common-interest associations" (Norbeck I 972) that operate within what these groups collectively define as Miyamoto-chō's bounda- 
ries. These are the chōnaikai and its women's auxiliary (fujinbu), the senior citizen's club (röjinkai), the festival committee (saireiiin), and the merchants' association (sbotenkai). Other organizations active in the neighborhood and surrounding areas include PTA's, local schools' alumni clubs (dōsōkai), politicians' support clubs (kōenkai), the volunteer fire brigade (shöbödan), and groups centered on hobbies such as travel, traditional dance, tea ceremony, or flower arrangement. Although each of these groups is formally independent, in practice their activities, leaderships, and memberships so interlock that it is difficult to disentangle one association from another.

The chonaikai is unquestionably the neighborhood's most important and visible organization. In some senses it acts as a semi-official local government, providing services to residents both at local initiative and at the behest of the municipal authorities. It serves as a conduit for demands, requests, and information that flow in both directions. The chōnaikai distributes information on government programs and regulations to residents and assists the government in record keeping, census taking, and conducting other surveys of local conditions. It lobbies the government on residents' behalf; one notable success (which the chonaikai achieved as part of a coalition of nearby neighborhoods) was getting the municipal government a decade ago to pave over a stream to build a traffic by-pass, and it played a role in getting the municipal government to build a new train station on a railway line near Miyamoto-chō. More modest accomplishments include pressuring a municipal nursery school to ban mothers from delivering their children by bicycle, thereby cutting noise and traffic congestion.

Local groups are involved in various mutual aid, public health, and safety activities. When death occurs, the chonaikai notifies residents, helps at the funeral, and makes the chonaikai meeting hall available for the wake. They aid in other emergencies as well; several years ago when a burlap bag factory burned to the ground, a family whose adjoining house was destroyed was put up in the chōnaikai hall for several months while their home was being rebuilt. Local associations have formed a disaster relief team (at government urging) and hold regular earthquake drills. They participate in traffic safety campaigns organized by the police, and provide free inspections of children's bicycles. Together the volunteer fire brigade and the chönaikai sponsor safety meetings and mid-winter patrols, and aid the professional fire department in extinguishing blazes. The chōnaikai maintains street lights on back alleys, and several times each summer a chōnaikai work crew sprays the entire neighborhood with pesticides. The chōnaikai and its women's auxiliary organize a monthly recycling drive, an important source of the groups' income.

Local organizations also sponsor many recreational activities. Children's outings to parks and playgrounds, and trips for adults to hot springs resorts are scheduled throughout the year. Annual events include neighborhood New Year's parties, a springtime cherry-blossom viewing party, a midsummer Bon Odori folk dance festival, and the autumn festival for the local Shinto tutelary deity. Even non-recreational events-such as the fire patrols, the pesticide spraying, or the earthquake drills-are opportunities for pleasant camaraderie that break daily life's normal routine, and often culminate in banquets or parties for the activities' planners and laborers.

Although perhaps no more than a quarter of Miyamoto-chō's households enthusiastically support and participate in the events and activities sponsored by the chonaikai and other local groups, monthly dues of 200 yen ( 00 yen for apartment dwellers) ${ }^{7}$ are collected from almost all households, and directly or indirectly the chönaikai's activities affect the lives of all residents. Through its public service, safety, and sanitation campaigns, the chonaikai improves the living environment of Miyamoto-chō; chōnaikai leaders also argue that by providing 


\section{28 ETHNOLOGY}

these services on a voluntary basis, the organization helps keep government expenditures, and taxes, lower.

The chonaikai and other formal groups also contribute heavily to the maintenance of the fabric of local social life; the relationships established among neighborhood residents through their participation in local groups and activities weave through and mutually reinforce ties established between individual residents in a wide variety of informal, non-institutional settings. Many of these informal ties would exist even in the absence of local organizations such as the chonaikai, but the presence of formally constituted groups provides a focus within which informal ties multiply, and local institutions reinforce the neighborhood's density of networks by providing convenient, generally recognized social boundaries. Viewed from another perspective, informal ties form a base without which many aspects of the formal organizations' activities could not function. Without the informal ties that run throughout Miyamoto-chō, consensual decision-making would be impossible, mutual aid and social control would fail, and the chonaikai and other groups would lack the means to mobilize residents to contribute time, labor, and money to neighborhood activities.

Examples of informal ties among residents are plentiful. The neighborhood is an important sphere of economic activity, and the local shopping street's sixty-odd businesses provide a wide spectrum of goods and services, for a primarily local clientele; almost all households do the bulk of their shopping for day-to-day needs within a couple of blocks from home. Most shopkeepers, craftspeople, factory owners, and even professionals, such as doctors, dentists, or accountants, conduct business in small shops, workshops, or offices attached to their homes, and family members are often involved in all aspects of the household enterprise. Since many businesses depend on local patronage, ties between customers or clients and the merchant or professional are often close; shops and offices frequently become neighborhood social centers as residents stop to chat over a cup of tea. Local tradespeople and professionals, therefore, play an important role in community life not simply because of the goods and services they provide but also because of the links they establish or maintain among other residents.

Another important example of neighborhood ties are the networks generated through the local elementary school, its PTA, and its alumni organization. As institutions, the various school-related organizations play significant social and political roles that are often central to community improvement campaigns. For example, the interlocking groups that make up the school community successfully led a drive to rid the school district of vending machines that sell pornographic magazines and comics. School centered groups also sponsor many recreational and social activities such as sports days, art exhibitions, and concerts that attract pupils and their parents, as well as many local residents who otherwise have no day-to-day connection with the school.

But, informal ties established through schools run throughout neighborhood life. For children, of course, the school and school-based groups are the central features of community life. For their parents, too, the school and its activities can be an engaging social arena. Often adults, particularly newcomers, are first drawn into community life through their children; adults become involved first in school-related activities and then, as their children grow up and their associations with other adults become firmer, the parents "graduate" to more general neighborhood groups and relationships. For local children who remain in Miyamoto-chō in adult life, former elementary school classmates often remain close friends, even decades after graduation. Once established, relationships among classmates may last a lifetime, cutting across occupational and status lines attained in adult life. When neighborhood networks intertwine as tightly as in Miyamoto-chō-where a shopkeeper's former classmate may be simultaneously a 
regular customer, a fellow official of the festival committee, a partner in chōnaikai activities, a political rival, and a parent of one's own child's playmate-old school ties can be important sources not just of friendship but also of political, economic, and social influence and obligation. For many residents of the area, connections to former classmates and the ability to classify innumerable other residents by their years of graduation and consequent relationships to oneself or one's relatives constitute an important, localized framework of social reference, which not only establishes recognized relationships between individuals who may never have had any direct interaction, but also provides a basis for exerting claims of mutual obligation, however weak, that can be used to win votes, attract and keep customers, exert social control, and mobilize people to participate in local events. $^{8}$

\section{The Neighborbood and the Government}

Together, the chōnaikai and other local groups define the basic social perimeters of Miyamoto-chō. These groups all share a common definition of the neighborhood and a common set of boundaries based on what local organizations and neighborhood residents regard as Miyamoto-chō's historically legitimate borders. Through their insistence on maintaining these boundaries, and through the activities they sponsor that give life to this definition of the neighborhood, they are successful in imposing their boundaries and their definitions on the municipal government, most directly on the branch office of the ward government.

This office handles various official transactions for individual residents and acts as a liaison between ten contiguous neighborhoods, including Miyamoto-chō, and the ward government. The ward regards chonaikai as little more than semi-official agencies of the government itself, and the branch office considers these ten chōnaikai to be under its jurisdiction. Chōnaikai leaders dispute this interpretation of their organizations' roles and complain (at least among themselves and to an inquiring anthropologist) about the responsibilities they are forced to shoulder by the government in pursuit of the government's rather than the neighborhoods' goals. Even at the semantic level there is disagreement over the nature of the relationship; the branch office refers to the ten cbonaikai together as a burokku (bloc) under its leadership, while the chonaikai see themselves as members of a rengō, or federation, for which the branch office is merely a source of advice and administrative support.

Beyond coordinating administrative functions, in recent years the branch office has become the focal point for the ward's increasingly active policy of machizukuri, or 'community-building.' Machi-zukuri policies appear to stem from the belief that existing patterns and institutions of neighborhood life as exemplified by chōnaikai are outmoded and inappropriate in contemporary society; the municipal government therefore feels it must step in and create institutions that will foster a sense of community and citizenship appropriate to a modern, democratic society. Ironically, in its attempts to do so, the municipal government takes the existing neighborhoods and their activities not only as the instruments but also as the models for creating new senses of community awareness (Nakamura i 980).

The branch office plans and sponsors a variety of traditionalistic activities that often duplicate events put on by individual neighborhoods themselves. Government-sponsored events frequently involve many of the same traditionalistic trappings common to the activities of chonaikai, and local leaders grumble about being upstaged by the larger, more lavish events the ward government can put on. One example is the extremely elaborate Kumin Matsuri (Ward Residents' Festival), modeled on customary Bon Odori folk dance festivals held in midsummer throughout Japan. The municipal government first sponsored the Kumin 


\section{I30 ETHNOLOGY}

Matsuri in I979, and it included a specially commissioned ward residents' folk song and a folk dance, both of which conform to the conventions of contemporary, commercialized "traditional" folk song and dance genres. The ostentatiousness of this first annual festival aroused so much ill will among chōnaikai leaders that the following year each of the eleven branch offices held separate scaleddown versions. But the ward festival continues to be more elaborate than the corresponding efforts of the chonaikai, and local leaders continue to complain about the "cooperation" they feel forced to give the branch office in its planning of this event.

If these conflicts seem subtle ones, they reflect an undercurrent of tension in the ongoing relationship between chonaikai and the ward government. The legal disestablishment of chonaikai in the early postwar period introduced ambiguities into the relationship that can lead to misunderstandings and disagreements on both sides; local leaders aware that the municipal government has no direct legal power over chōnaikai complain of the government's overbearing attitudes, and insist that local organizations must be regarded as voluntary bodies organized by and for local residents. Furthermore, the postwar political climate has weakened citizens' subservient attitude toward government officials. Citizens now feel empowered to object to authoritarian directives from the municipal government, and complain that officials often seem to forget they are public servants. On top of this, tensions have been spawned by the ward's machi-zukuri policies, whose apparent intention has been to supplant chōnaikai both as semi-official administrative units and as focal points of local residents' activities and identification (cf. Falconeri 1976). These sources of strain in relations between neighborhoods and the government creates the potential for dramatic rifts.

An example of such conflict is a dispute over the neighborhood's boundaries, and hence between external and internal definitions of what the neighborhood is. In I 964 the ward attempted to amalgamate Miyamoto-chō with an adjacent neighborhood. To an outsider almost nothing differentiates the neighborhoods, yet their residents successfully opposed the merger. True, the municipal government went ahead and redrew the boundaries, and now the two neighborhoods appear on maps as one unit. But today that larger unit is used for almost nothing but numbering houses. The chonaikai and other local groups do not recognize the larger unit, nor does the ward office; since the ward office depends on the chonaikai to carry out many of its tasks, it is forced to work within frameworks chōnaikai acknowledge.

Residents of the neighborhoods involved have political and economic interests that would not have been served by a merger. Each neighborhood has routinely been able to elect a member to the ward assembly, so there were political jiban (territory or "turf") to protect; similarly, merchants' groups in each neighborhood strive to maintain and increase their share of local trade in the face of competition not only from other neighborhoods but also from the large shopping district around a nearby railway station. But when they are asked about their resistance to the merger, these are not the reasons mentioned by residents; instead, they explain resistance as an effort to preserve the "distinct" traditions and ways of doing things in the neighborhoods involved. Whether in the ways donations are collected for the annual festival, in the relationships between the chonaikai and merchants' association, or in the ways representatives from each neighbor group are selected, each neighborhood was unwilling to alter practices they felt best suited their own needs and their own sense of autonomous tradition and identity. These sentiments, in Miyamoto-chō at least, revolved around the neighborhood hall. The issue was not simply a question of sharing ownership of a ramshackle building, but involved symbolism central to the neighborhood's self-definition.

At the time, Miyamoto-chō was the only neighborhood in the area to have its own hall. During the last year of World War II, as American air raids struck 
Tokyo more and more frequently, the residents of Miyamoto-chō were ordered to create a firebreak along the adjacent right-of-way of a vital freight line. To create the break, the men and boys of the chonaikai tore down the homes on either side of the tracks. From the lumber and roof tiles they salvaged enough to build the neighborhood hall. This hall is now an aging relic, and compared with newer halls built or acquired by other neighborhoods in the area, it is small and dilapidated, but still the center of local activity and an important symbol of the neighborhood as a community. The prospect of sharing this and other tangible or intangible cultural properties with outsiders was an important rallying point for opposing the ward government's plans, and ultimately this opposition proved successful.

A similar expression of community sentiment, indirectly related to neighborhood boundaries and their defense, can be found in the annual autumn festival (aki matsuri) for the local Shintō tutelary deity. The two-day matsuri is a vivid symbol of the community and it draws wide participation. It is, of course, a Shintō rite, but for most residents of Miyamoto-chō the matsuri is essentially a secular ritual, largely lacking explicit religious significance but replete with social meaning.

Through the matsuri, several important though sometimes contradictory social themes are expressed. The festival is organized by a festival committee (saireiiin) convened each summer by the chonnaikai, but made up of leaders from various local associations as well as residents who otherwise take no active part in neighborhood affairs. Social stratification and ranking within Miyamoto-chō are expressed and enforced through assignments of positions on the festival committee, and by public postings of residents' contributions. Distinctions are underscored between newcomers and longer-term residents. The management of the festival, and even the spatial and temporal distribution of activities during the matsuri, reflect rigid sexual and age-graded divisions of labor. Despite the social rankings that play so visible a role, an overt spirit of egalitarianism and community solidarity is presented as the matsuri's dominant motif.

The matsuri also serves as a compelling marker of the community's boundaries and identity. A central feature of the festival is the mikosbi, a portable shrine or palanquin in which the tutelary deity temporarily resides during the two-day festival. The mikoshi, carried on a framework of poles by a group of twenty or more young men (and recently women) is taken on what amounts to an inspection tour of Miyamoto-chō; the procession carefully traces the neighborhood's boundaries. When the route of a mikoshi unavoidably must pass through the territory of an adjacent neighborhood-when roads or alleys linking parts of one neighborhood run through another, or when mikoshi are brought from other neighborhoods to the shrine in Miyamoto-chō for the priest's blessings-the festival committees from the neighborhoods involved negotiate the route beforehand. When a mikoshi, or a women's dance troupe, takes a sudden detour through another neighborhood, leaders from the transgressed neighborhood grumble and expect an apology from the festival committee of the offending neighborhood.

Although the matsuri nominally encourages cooperation and identification with the six other neighborhoods that make up the shrine's parish, the mikosbi and their processions provide a venue for inter-neighborhood competition. In recent years the neighborhood next-door to Miyamoto-chō triumphed with an impressive new mikoshi, hand-built by local young men, but during I979-8 I Miyamotochō countered by prominently featuring in its processions the as yet unsurpassed spectacle of a foreign anthropologist and his exotic red-haired wife. But, in the longer term other strategies were required to uphold the neighborhood's standing. In the spring of $\mathrm{I} 982$ younger neighborhood leaders launched a drive to raise funds for a new mikoshi; within three months, Miyamoto-chō raised almost $\$ 50,000$ in cash and pledges from over 400 local households, and by the 


\section{I32 ETHNOLOGY}

time of the 1982 festival, the neighborhood had bought the largest, most elaborate mikoshi in the area. Leaders of the fundraising campaign claim a major objective was to increase participation in the festival and hence in neighborhood affairs by making the local festival more impressive and exciting, but they also point out with pride that Miyamoto-chō's new mikoshi is more impressive than the adjacent neighborhood's hand-built one, and talk with unconcealed pleasure about the failure of another adjoining neighborhood to meet the challenge.

Through events such as the festival, and dozens of other, more mundane activities throughout the year, the chonaikai and other local groups staunchly defend the neighborhood's present-day boundaries and their definitions of the local community. By maintaining Miyamoto-chō's sense of identity and upholding the distinctiveness of each of the local neighborhoods, activities such as the festival contribute to a sense of resistance to government efforts to reconstitute local social units as part of its machi-zukuri policies. Opposition to the government is not the only, nor even the most important outcome of such activities, for through their participation in events such as the festival residents maintain the neighborhood as an arena for valued social interactions that bestow prestige, status, and recognition on their leaders and participants in ways not duplicated elsewhere in their lives.

In these examples, and in the more general process of socially constructing its identity, institutions and residents of Miyamoto-chō define the neighborhood by referring to particular aspects of its history and its customary practices, selecting out certain events or activities with which to press their case. Although many of the events or institutions to which they refer are recent in occurrence or origin, this does not diminish their utility or significance as emblems of neighborhood tradition and distinctiveness. As several scholars have noted, Japanese social institutions have a penchant for "instant tradition"- the ability to cloak new circumstances and institutions with a mantle of traditionalism, imparting depth and resiliency to what might otherwise have shaky foundations (Brown 1976; DeVos, personal communication; DeVos and Wagatsuma 1973).

\section{CONCLUSIONS}

In this brief outline of Miyamoto-chō's contemporary social patterns, as well as of the neighborhood's historical development, I have attempted to suggest the complexity and richness of the social life that local institutions and networks sustain. Many aspects of the neighborhood's formal and informal structure are administrative in character, and the entire ethos of the local community lends itself to potentially political forms of mobilization. However, Miyamoto-chō does not exist as a solely political or administrative entity. The community is created and maintained by a variety of social, economic, and political ties, and to conceive of it exclusively in political or administrative terms would seriously misrepresent the motivations and perceptions of many of those who are most active in neighborhood affairs.

Furthermore, the local government's political and administrative relationships with the neighborhood are complex and bilateral, not unilateral. To be sure, the chōnaikai's leaders and active members are generally conservative and usually cooperative in their dealings with the government. Nonetheless, by drawing on particular features of the neighborhood's history and by emphasizing communal solidarity through various traditionalistic activities, Miyamoto-chō defines itself in terms different from and independent of the definitions the local government attempts to impose. This sense of community is the basis, in principle and occasionally in practice, for opposing or defying the municipal government.

The ward government, on the other hand, continues to rely on chonaikai to carry out many tasks, but at the same time pursues policies that seek to lessen community identification and solidarity at the level of neighborhoods such as 
Miyamoto-chō, and to redirect those sentiments toward an institutional level directly under its control. To do this, the government competes with chönaikai on the neighborhood's own terms because many of the activities and organizational forms promoted by the ward are modeled after those of chönaikai and drawn on some of the same traditionalistic idioms that chonaikai draw upon. The effect appears not to be a weakening of the chonaikai's position, but a further legitimation of traditionalistic activities and organizational patterns, and the chönaikai responds to government challenges with an intensification of traditionalism.

Miyamoto-chō's residents as well as scholars of Japanese urban life frequently portray seemingly stable patterns of neighborhood social life as a matter of simple continuity with the traditions of the past. But neither the institutions nor their traditionalism can be taken as historical givens. They are not the products of social stasis; they developed during periods of great social change. Miyamoto-chō was created during Tokyo's urban growth; it is successor to neither a rural hamlet nor a preindustrial merchant quarter. In contemporary as well as historical perspectives, Miyamoto-chō as an organized community emerges as a response both by individual residents and by governmental bodies to a variety of social, political, and demographic features of the urban environment that require collective action, action necessitated by both internal community needs and demands externally imposed upon the neighborhood. Although idioms of traditionalism and elements of traditional social patterns are invoked in the symbolic creation and maintenance of the neighborhood as a community, this should not blind analysts from examining them for what they are-consciously and unconsciously manipulated metaphors-rather than for what they are not-evidence of historical continuity or cultural stagnation of the individuals and social groups involved.

Many analyses of contemporary Japanese society fail to recognize these points; this failure distorts our understanding not only of urban neighborhoods, but of social patterns throughout all realms of Japanese society and the processes of social change that have shaped them. Analyses that place the locus of Japanese social structure firmly in the social patterns of the past, or argue that resemblances between the rural past and the urban present result from static continuity explain little. They perpetuate a view of social change as involving simple movement along a continuum between rural and urban, traditional and modern. They relegate those aspects of society and culture deemed traditional to a limbo in which no further explanation or analysis is required, and they fail to examine the dynamic manipulation, reinterpretation, and creation of supposedly static tradition that takes place during the process of social change. They rely, as R. J. Smith (1973:164) puts it, on "invented history: explanations of ... contemporary phenomenon .... in terms of an imagined past condition from which change is believed to have occurred."

\section{NOTES}

I. This article is based on research for my doctoral dissertation (Bestor 1983a), and I gratefully acknowledge support from the following organizations that made fieldwork during I979-8I possible: the Japan Foundation, the National Science Foundation, the National Institute of Mental Health, the Joint Committee on Japanese Studies of the American Council of Learned Societies and the Social Science Research Council, and the Center for Research in International Studies, Stanford University. A grant from Sigma Xi assisted during a brief return visit to Miyamoto-chō in September 1983 .

I am indebted to Toshiko Bunya of Tokyo Metropolitan University for her extremely able aid during several periods of the research. This article has benefited greatly from comments by Gary $D$. Allinson, Harumi Befu, Dorothy K. Bestor, L. Keith Brown, Gilbert H. Herdt, Nozomu Kawamura, Victoria Lyon-Bestor, Emiko Ohnuki-Tierney, James W. White, and Sylvia J. Yanagisako.

2. The names Miyamoto-chō and Kumodani (used below) are pseudonymous.

3. These figures are calculated from household residence registers (jümin törokubyō) maintained by the municipal government. The figures include about 180 single male residents of two company 


\section{I34 ETHNOLOGY}

dormitories located in Miyamoto-chō, each of whom is counted by the government as a single household. Neighborhood organizations do not consider these men full-fledged residents, and they rarely are involved in local events.

4. Chōnaikai are also generically called chökai or jichikai, and are known by a wide variety of local names as well. There is no consensus on the appropriate English translation for these terms, and several glosses are commonly used. Unfortunately, different authors use the same English terms to refer to different levels in the institutional framework of neighborhood life. In this article I use "neighborhood association" for chōnaikai, chökai, and jichikai; "neighbor group" for tonarigumi; and "ward" for $k u$ (governmental subdivisions that in Tokyo have populations of several hundred thousand) (cf., Dore 1958, I968; Supreme Commander for the Allied Powers 1948, I949).

5. Discussions of shitamachi as a contemporary social category may be found in Dore (I958), R. J. Smith (1960), and Bestor (1983b).

6. Although seemingly dramatic population increases often have been caused by mergers and amalgamations of towns and village, the boundaries of the administrative unit known in the early I 920 s as Hiratsuka-mura remained unchanged from I 889 to I 947 , and here population growth was caused solely by in-migration and natural increase.

7. During I979-8I, 200 yen was equivalent to slightly less than U.S. \$I.00.

8. Elementary school ties provide a broad basis for establishing these links throughout the immediate area; a directory (published by the local elementary school's alumni club in I 979 to commemorate the school's fiftieth anniversary) shows that about one fifth of all graduates still live within the school's district, where these graduates constitute about 20 per cent of the district's total population of approximately i I, OOO.

\section{BIBLIOGRAPHY}

Allinson, G. D. I979. Suburban Tokyo. Berkeley.

Bellah, R. N. I957. Tokugawa Religion. Glencoe.

Bestor, T. C. I983a. Miyamoto-chō: The Social Organization of a Tokyo Neighborhood. Ph.D. dissertation, Stanford University.

I 983b. Shitamachi. Kodansha Encyclopedia of Japan vol. 7, pp. I49-50. New York and Tokyo.

Braibanti, R. J. D. I 948 . Neighborhood Associations in Japan and Their Democratic Potentialities, Far Eastern Quarterly 7:1 36-64.

Brown, L. K. I976. Community and The Territorial Principle. (ms.).

DeVos, G. A., and H. Wagatsuma. I973. The Entrepreneurial Mentality of Lower-Class Urban Japanese in Manufacturing Industries. Socialization for Achievement, ed. G. A. DeVos, pp. 20I-I9. Berkeley.

Dore, R. P. I958. City Life in Japan. Berkeley.

1968. Urban Ward Associations in Japan. Readings in Urban Sociology, ed. R. E. Pahl, pp. I 86-90. Oxford.

Ebara-kuyakusho. I943. Ebara-ku Shi. Tokyo.

Falconeri, G. R. I976. The Impact of Rapid Urban Change on Neighborhood Solidarity. Social Change and Community Politics in Urban Japan, eds. J. W. White and F. Munger, pp. 3 I-59. Chapel Hill.

Fukutake, T. I962. Man and Society in Japan. Tokyo.

I981. Japanese Society Today. (Second edition) Tokyo.

Hastings, S. A. I980. The Government, the Citizen, and the Creation of a New Sense of Community. Ph.D. dissertation, University of Chicago.

Havens, T. R. H. I978. Valley of Darkness. New York.

Hozumi, S. I943. The Tonari-Gumi of Japan. Contemporary Japan I 2:984-90.

Inoue, K. I932. Ebara-machi Shi. Tokyo.

Ishida, T. I97 I. Japanese Society. New York.

Ishizuka, H. I977. Tōkyō no Shakai Keizai Shi. Tokyo.

Isomura, E., and M. Okuda. I 966 . Recent Trends of Urban Sociology in Japan. Japanese Sociological Studies, ed. P. Halmos, pp. 127-50. Keele.

Kagami, Z. I935. Dai Ebara Sōran. Tokyo.

Kurabayashi, Y. I983. Kantō Daishinsai no SSDS. Keizai Kenkyū 34:97-I I I.

McKean, M. A. I976. Citizens' Movements in Urban and Rural Japan. Social Change and Community Politics in Urban Japan, eds. J. W. White and F. Munger, pp. 6I-99. Chapel Hill.

198r. Environmental Protest and Citizen Participation in Japan. Berkeley.

Masland, J. W. $\quad$ I946. Neighborhood Associations in Japan. Far Eastern Survey. I 5:355-58.

Nakagawa, G. I980. Chōnaikai. Tokyo.

Nakamura, H. I979. Senzen no Tōkyō ni okeru Chōnaikai. Tokyo.

I 980. The Concept of Community Transplanted in Japan. Asian Perspectives on Social Development, eds. S. Koyano, et al, pp. 79-89. Tokyo.

Nakane, C. I970. Japanese Society. Berkeley.

Norbeck, E. I972. Japanese Common-Interest Associations in Cross-Cultural Perspective. 
Journal of Voluntary Action Scholars $1: 38-4 \mathrm{I}$.

Okuda, M. I964. Kyūchūsansō o Shūtai to suru Toshi Chōnaikai. Shakaigaku Hyōron I4:9-1 4. Seidensticker, E. I 983 . Low City, High City. New York.

Shinagawa-ku. 1973-74. Shinagawa-ku Shi: Tsūshi-hen. (2 Volumes). Tokyo.

Shinagawa-ku Kyōiku linkai. 1979. Shinagawa no Rekishi. Tokyo.

Smith, H. D. I 978 . Tokyo as an Idea. Journal of Japanese Studies 4:45-80.

Smith, R. J. 1960. Pre-Industrial Urbanism in Japan. Economic Development and Cultural Change $9(\mathrm{I}$, part II):24I-57.

1973. Town and City in Pre-Modern Japan. Urban Anthropology, ed. A. Southall, pp. 163-2 IO. New York.

Steiner, K. 1965. Local Government in Japan. Stanford.

Supreme Commander for the Allied Powers.1948. A Preliminary Study of the Neighborhood Associations of Japan. Tokyo.

I 949 . Political Reorientation of Japan. (2 Volumes). Washington.

Suttles, G. D. I 972 . The Social Construction of Communities. Chicago.

Tōkyō-fu. I921. Tōkyō-fu Tōkeisho. Tokyo.

I930. Tōkyō-fu Tōkeisho. Tokyo.

Tōkyō-to. 1972-80. Tōkyō Hyakunen-shi. (7 Volumes). Tokyo.

White, J. W. I976. Social Change and Community Involvement in Metropolitan Japan, Social Change and Community Politics in Urban Japan, eds. J. W. White and F. Munger, pp. IOI-29. Chapel Hill. I982. Migration in Metropolitan Japan. Berkeley.

Yanagisako, S. J. (In press). Transforming the Past. Stanford. 